\title{
LESOTHO'S FEBRUARY 2015 SNAP ELECTIONS: A PRESCRIPTION THAT NEVER CURED THE SICKNESS
}

\section{Tlohang W Letsie}

Tlohang W Letsie is a PhD candidate in the Peacebuilding Programme at the Department of Public Management and Economics,

Durban University of Technology, South Africa. email: tlohangletsie@gmail.com

\begin{abstract}
Within just two years of its existence, Lesotho's first coalition government experienced serious internal conflicts. These conflicts were mainly the result of the coalition leaders' failure to balance coalition agreements against the country's Constitution. The conflicts paralysed the government and the National Assembly, and polarised security establishments. These political developments required mediation by the Southern African Development Community (SADC), which in turn led to holding 'snap elections' in February 2015. This paper discusses the snap elections. Although the elections helped to form and legitimise a new coalition government, they did not resolve the structural challenges that had paralysed the first coalition government. By calling for an early election, SADC mediation failed to prioritise a solution to the security crisis in Lesotho. Security agencies remain polarised, and some politicians have aligned themselves with those agencies to enhance their influence in national politics. The paper concludes that the snap elections provided only a short-term solution to Lesotho's political and security problems. The new coalition government is likely to experience the same fate as its predecessor. Furthermore, rule of law is likely to be compromised by the new coalition government for the sake of internal stability.
\end{abstract}

Keywords: 2015 snap election, coalition government, conflict, security crisis. 


\section{INTRODUCTION}

This article examines the February 2015 snap elections in Lesotho, and the likely effects of the election results on the political stability of the country. The paper includes descriptive and predictive analyses. The information was drawn from secondary sources, including academic journals; textbooks; official documents from the Independent Electoral Commission (IEC), the government, and political parties; political parties' agreements; and newspapers.

The paper is divided into five sections. The first section provides a theoretical explanation of elections. The second section gives a brief overview of the post2012 coalition government and the build-up to the February 2015 snap elections. In the third section, the February 2015 snap elections are examined in detail. In the fourth section, the scenarios likely to face the new coalition government are examined. The fifth section offers some concluding remarks.

\section{BACKGROUND}

On 28 February 2015, Lesotho held its third 'snap election' in 13 years. The others were held in 2002 and 2007 respectively. Normally, Lesotho's Parliament has a fiveyear tenure. The 2002 snap elections arose from a dispute over the 1998 election results, which prompted the Lesotho Congress for Democracy (LCD) government to bring the 2003 elections forward by a year. The disputes had caused political uprisings in which members of opposition parties had revolted against the LCD government. The opposition members had forcefully closed government offices and confiscated government vehicles.

The next elections were scheduled for May 2007. These elections were also 'fast-tracked' by three months to February 2007. This decision was made after the then Prime Minister Pakalitha Mosisili advised King Letsie III to dissolve Parliament and call for an early election. Mosisili's move came after the split of his party - the LCD - and the subsequent formation in Parliament of the All Basotho Convention $(\mathrm{ABC})$. The split had left the LCD with a slim majority of two seats. By calling for the dissolution of Parliament, Mosisili avoided a vote of no-confidence, as there were signs that more members of Parliament (MPs) intended to leave the $\mathrm{LCD}$ for the $\mathrm{ABC}$.

The February 2015 snap elections happened just over two years earlier than scheduled, after the premature dissolution of the eighth Parliament. The eighth Parliament was dissolved midway because of a falling-out between leaders of the three-party coalition government, which was formed after the May 2012 elections failed to produce an outright winner. The coalition government had consisted of the $\mathrm{ABC}$, the LCD and the Basotho National Party (BNP). These three parties 
had secured 30, 26, and 5 parliamentary seats respectively - a total of 61 seats for the coalition. The Lesotho Parliament consists of 120 seats. To form a government by a party, or coalition of parties, a minimum of 61 seats is needed (Constitution of Lesotho 1993, Section 87 (2)). Thomas Thabane of the ABC became the prime minister and was deputised by Mothejoa Metsing of the LCD. The BNP's Thesele 'Maseribane became the Minister for Gender, Youth, Sports and Recreation.

The coalition government was generally seen as a positive step in the country's democratic journey. It marked the end of fourteen years of rule by Pakalitha Mosisili, first under the LCD and later under the Democratic Congress (DC). Mosisili had left the LCD to form the DC in February 2012, and continued as the prime minister under the new party until he was ousted in the May 2012 elections.

Despite the coalition government being widely celebrated, cracks began to show soon after it came to power. The conflict mostly pitted Prime Minister Thomas Thabane and Minister Thesele 'Maseribane on one side versus Deputy Prime Minister Mothejoa Metsing on the other. Metsing accused Thabane of taking major decisions arbitrarily and without consulting him as his deputy. Thabane, on the other hand, justified his alleged 'arbitrariness' as being in line with the country's Constitution.

The conflict between the coalescing parties intensified with time, and began to affect other political institutions such as the National Assembly and the armed forces. Metsing and his party (LCD) received sympathy and support from the main opposition party (DC) and smaller opposition parties. Together, the opposition parties tried to pass a 'no confidence' motion on Prime Minister Thabane. Thabane thwarted this attempt by advising King Letsie III to prorogue Parliament for nine months. However, despite being the minister responsible for defence and national security, Thabane had lost control over the country's defence force. The defence force commander, Lieutenant General Tlali Kamoli, had obvious sympathies towards Deputy Prime Minister Metsing. When Thabane realised this, he fired Kamoli for alleged insubordination, and in August 2014 he replaced Kamoli with Lieutenant General Maapara-nkoe Mahao. But Kamoli refused to step down and Mahao never had the chance to resume his appointed role.

\section{INVOLVEMENT OF THE SADC}

As the army continued to show sympathy to Metsing and his party (LCD), the police came to be associated with Thabane and his party (ABC). Relations between the two security organs - the police and the defence force - quickly soured and at times became violent. Coupled with these deteriorating relations, the prorogation of Parliament intensified the political instability and security crisis to a level that 
required intervention by the South African Development Community (SADC). Various forums were held. Eventually the SADC Troika mandated South African Deputy President Cyril Ramaphosa to help Lesotho regain political normalcy and stabilise its security situation.

Political stability was partly restored after Ramaphosa facilitated the signing of the Maseru Facilitation Agreement (MFA) and the Maseru Security Accord (MSA). The MFA enabled Lesotho's Parliament to re-open in September 2014, four months before the initially planned nine-month period. It also allowed the elections to be brought forward by two years to February 2015. The MSA called for the two Defence Force generals and the Commissioner of Police, Khothatso $\mathrm{T}^{\prime}$ sooana, to take leave of absence outside Lesotho. This move was intended to allow the army and police to reconcile and re-establish good relations.

Despite the reopening of Parliament in September 2014 and the fasttracking of elections, relations between the feuding coalition partners remained antagonistic. The government literally collapsed, although the three parties' ministers remained in their respective positions. Despite this dark cloud hovering over their country, the Basotho people remained hopeful that the elections would usher in a new era of peace and stability. They hoped for better circumstances that would develop the country and improve citizens' well-being.

\section{CONCEPTUAL FRAMEWORK}

Representative democracy is intrinsically linked to elections and voting. The two processes are so linked that some thinkers have portrayed elections as the very heart of democracy. For instance, Schumpeter (cited in Heywood 2007, p. 253) views democracy as an

institutional arrangement - a means of filling public office by a competitive struggle for the people's vote. As he [Schumpeter] put it, democracy means only that the people have the opportunity of accepting or refusing the men [sic] who are to rule them.

In this sense, Schumpeter equates democracy with elections, particularly competitive elections. However, many contemporary writers, such as Schedler (2002, p. 37 cited in Masunungure 2014, p. 97), have challenged Schumpeter's view of democracy, arguing that democracy means far more than elections and includes various interactions between the electorate and the government. These theorists draw a distinction between democracies by naming one type 'electoral democracy' and the other 'liberal democracy'. 
Electoral democracies, typified by Schumpeter's view of elections as democracy, are a common feature in some Third World countries. In these countries the role of the general public in national affairs ends at the election booths. According to Schedler, however, such electoral democracies 'manage to get elections right, but fail to institutionalise other vital dimensions of democratic constitutionalism, such as the rule of law, political accountability, bureaucratic integrity, and public deliberation' (Schedler 2002, p. 37, cited in Masunungure 2014, p. 97).

Elections fulfil various functions, including the making of governments. Elections can form governments both directly and indirectly. They form governments directly only in presidential systems where the political executive is directly elected. In parliamentary systems, elections influence the formation of governments mainly where electoral systems such as the 'first past the post' tend to give a single party a clear parliamentary majority. However, under systems such as proportional representation and mixed models, such as in Lesotho, governments are usually formed through post-election deals. This implies that governments can be made and unmade without the need for elections.

Another important function of elections is to build legitimacy for a government. This is mostly the case in troubled systems where elections are organised and are typically rigged to produce a pre-determined outcome, usually in favour of the incumbent party. In such cases the elections merely provide justification for the party's prolonged rule. Elections, even those that are not free and fair, are always labelled as the manifestation of the people's will. These claims are usually accompanied by slogans such as 'the people have spoken'.

\section{CONTEXT OF THE 2015 ELECTIONS}

It is crucial to discuss and illustrate the context within which the February 2015 snap elections were held. To do so, one must first understand the logistics of the dissolved first coalition government and the eighth Parliament. This overview provides the basis for a comparison from which a premise can be drawn, to predict the challenges likely to be faced by the new Parliament and government born out of the 2015 snap elections.

\section{The Rise and Fall of Lesotho's First Coalition Government}

The short-lived eighth Parliament of Lesotho and its offspring government resulted from the May 2012 elections, the results of which are shown in Table 1 below. 
Table 1

Final Seat Allocation in Lesotho's 8th Parliament

\begin{tabular}{|l|r|r|r|r|r|}
\hline Party & \multicolumn{1}{|c|}{$\begin{array}{c}\text { Total Party } \\
\text { votes }\end{array}$} & $\begin{array}{c}\text { Party's } \\
\text { quota's of } \\
\text { votes }\end{array}$ & $\begin{array}{c}\text { Constituency } \\
\text { seats won by } \\
\text { the party }\end{array}$ & $\begin{array}{c}\text { Party's } \\
\text { provisional } \\
\text { allocation of } \\
\text { PR seats }\end{array}$ & $\begin{array}{c}\text { Total } \\
\text { number of } \\
\text { seats }\end{array}$ \\
\hline ABC & 138,917 & 30.21 & 26 & 4 & 30 \\
\hline BBDP & 2,440 & 0.53 & 0 & 1 & 1 \\
\hline BCP & 2,531 & 0.55 & 0 & 1 & 1 \\
\hline BDNP & 3,433 & 0.75 & 0 & 1 & 1 \\
\hline BNP & 23,788 & 5.17 & 0 & 5 & 5 \\
\hline DC & 218,366 & 47.49 & 41 & 7 & 18 \\
\hline LCD & 121,076 & 26.33 & 12 & 14 & 1 \\
\hline LPC & 5,021 & 1.09 & 0 & 1 & 1 \\
\hline LWP & 2,408 & 0.52 & 0 & 1 & 2 \\
\hline MFP & 3,300 & 0.72 & 0 & 1 & 3 \\
\hline NIP & 6,880 & 1.50 & 0 & 2 & 0 \\
\hline PFD & 11,166 & 2.43 & 1 & 2 & 120 \\
\hline Others & 12,400 & 0 & 0 & 0 & 40 \\
\hline Totals & 551,726 & & 80 & & 1 \\
\hline
\end{tabular}

Source: IEC Lesotho National Assembly Elections Final Seat Allocation (May 2012).

The allocation of seats meant that the elections produced a hung Parliament, with no political party winning an absolute majority of more than 60 seats. Thus the parties were compelled to negotiate with a view to forming a coalition government. From the start it was clear that these negotiations were driven by the desire to access office rather than by policy goals. Essentially, political parties in Lesotho have no substantial differences in their policies. This lack of policy differentiation was evident in the parties' manifestos, which were virtually replicas of one another.

With a relative majority of 48 seats, the DC was best placed to find a partner. The DC needed just 13 more seats to reach the constitutional 61 seats needed to achieve a party or coalition so as to form a government. The second-placed $\mathrm{ABC}$ had 30 seats, which meant it needed another 31 to take over in government. The $\mathrm{DC}$ and the $\mathrm{ABC}$ were thus the two 'favourites' to lead a potential coalition government. With 26 seats, the third-placed LCD became the 'key-holder' in deciding the new coalition government. It was clear that the ABC and DC would not join together to form a government, given the antagonistic relations between 
their leaders and members in general. Based on their pole positions, the $A B C$ and DC both approached the LCD in the hope of forming a coalition government.

The 'horse-trading' to form a coalition government became pressured and had to be completed within two weeks. The Constitution of Lesotho states that the National Assembly must convene and a new government must be formed within a maximum of fourteen days after the announcement of an election's results. Ultimately the $\mathrm{ABC}$ won the support of the $\mathrm{LCD}$. These two parties became the leading parties in a three-party coalition that included the BNP. This situation is an example that contradicts the assumption that a party having the most representatives will become central in the legislature when a coalition government is formed. Other examples have been Mauritius after its 1976 general elections, and South Africa's provincial elections in the Western Cape in 1999. In both cases, parties that had won the most seats were kept out of government by the coalition of smaller parties (Kadima 2006, p. 8).

The coalescing parties (ABC, LCD and BNP) formalised their agreement in a document titled 'Agreement to Form a Coalition Government of Political Parties: Subsequent to the May 262012 National Elections'. It was signed by the leaders of the three parties. Collectively, the three parties had 61 seats, implying that their government had a precarious one-seat majority. To minimise the risks associated with such a slim majority, the three coalescing parties solicited the support of six other smaller opposition parties represented in Parliament. These six parties formed an alliance that came to be known as 'the Bloc'.

Although the Bloc formally remained outside the coalition government, the six parties pledged to vote with the coalescing parties. Collectively the Bloc had seven seats, which meant the overall coalition was assured of 68 votes during parliamentary polls. This development meant that although the DC had won a relative majority of 48 seats, it was pushed to the opposition benches. This scenario can largely be explained by the insistence of the DC's leadership, before the elections, that the party was going to win outright and would not need to form a coalition government. Furthermore, it was always going to be difficult for the DC to woo other parties, because among the opposition parties, the general (though unofficial) theme of the 2012 elections had been 'change'. This would mean ending Mosisili's fourteen-year rule.

Thus, from the start it was clear that the country's new coalition government was not the result of ideological considerations. It was largely a marriage of convenience determined by the desire of the parties to bring about change. The electorate itself wanted a change in government; fourteen years of rule by Mosisili had failed to rid the country of social ills such as poverty, unemployment, crime and corruption. Although the LCD was by now also calling for Mosisili's departure, Mosisili had ruled for more than 13 years as the leader of the party. Only three months of his rule were under his new party, the DC. 
In handing over the reins of government to incoming Prime Minister Thabane on 8 June 2012, Mosisili acknowledged that his administration had failed to deal with a number of problems, most notably corruption within government structures. Thabane had always been vocal about fighting corruption, and his party had this aim as one of the core points in its electoral manifesto.

\section{Trouble in the Coalition Government}

Thabane was sworn in as the new prime minister, and as per the coalition agreement he was deputised by Metsing of the LCD. 'Maseribane of the BNP became the Minister for Gender, Youth, Sports and Recreation. Thabane later announced his Cabinet. The ABC received eleven ministries, the $\mathrm{LCD}$ received ten, and the BNP received two.

Notable in the Cabinet allocation was that the LCD had taken what can be described as the most strategic ministries. These included Finance; Foreign Affairs; Public Works; Communications, Science and Technology; Local Government and Chieftainship Affairs; and Education. Among others, the ABC received Defence; Police and National Security; Justice; and Mining. The BNP gained Home Affairs and the Ministry of Gender, Youth, Sports and Recreation - which was headed by its leader. It was clear that the LCD had wisely used its 'kingmaker' position as a bargaining tool in negotiations with the other two parties.

Interestingly, as the three parties were partitioning the government ministries and ambassadorial posts among themselves, the Bloc did not feature anywhere. This was despite it being a pillar of strength for the coalition government. It later came to light that the Bloc parties had expected to be awarded influential posts such as District Administrators. This never happened. The anger and vengeance of the Bloc against Thabane's coalition government became a decisive feature in the formation of the post-2015 elections coalition government, as discussed later in this paper.

After only two years in power, the coalition government began to experience serious internal squabbles. Deputy Prime Minister Metsing began to accuse Prime Minister Thabane of running the tripartite coalition like a one-man show and making crucial decisions without consulting other partners. The other partner, 'Maseribane, however, did not level the same accusations.

Some of the alleged unilateral decisions Thabane was accused of included firing the Government Secretary, Motlatsi Ramafole, and the Commander of the LDF, Tlali Kamoli; trying to take control over the management of the Lesotho Highlands Water Project; and advising King Letsie III to prorogue the eighth Parliament. Tensions within the coalition government were further fueled when the Lesotho Mounted Police Services and the Directorate on Corruption 
and Economic Offences (DCEO) brought criminal charges against certain highranking officials, including ministers of the coalition government and those of its predecessor under the leadership of Pakalitha Mosisili. They included the following officials:

- Former Minister for Natural Resources and deputy leader of the DC, who was also the official leader of the opposition: Monyane Moleleki;

- Deputy Prime Minister Mothejoa Metsing;

- Minister of Natural Resources, Timothy Thahane; and

- Minister of Communications, Science and Technology: Selibe Mochoboroane.

Thahane was later relieved his duties as the Minister for Natural Resources. The cases listed above formed the core of the dispute that led to the collapse of the coalition. Those which are most relevant to this paper are briefly discussed in the next paragraphs.

Metsing and his party said that some of the charges had been initiated by Thabane, whom they accused of using state organs to fight his political battles and humiliate his opponents (Tefo 2014a, p. 3). Thabane defended himself against these alleged misdeeds. With regard to charges instituted against people suspected of criminal activities - mostly corruption, he emphasised in his speeches that he was not responsible for laying charges against anyone and that this was the duty of the relevant state arms, such as the police and DCEO. He was consistent in arguing that such state arms should be free to arrest and charge anyone (including himself) irrespective of the person's position, if those bodies felt such a person had a case to answer. Thabane also defended his alleged non-consultation by referring to the sections of the country's Constitution that gave him, as the 'Chief Executive' of the government, the power to make decisions.

\section{High-profile Corruption Charges}

In June 2013, former Minister for Natural Resources and incumbent deputy leader of the DC, Monyane Moleleki, was charged with fraud and corruption. This was for 'allegedly diverting M15 million meant for a mining electrification project in Kao, Liqhobong and Lemphane mines and a nearby village of Kaonyana, to villages in his Machache constituency' (Molomo \& Tlali 2013, p. 6). ${ }^{1}$

Moleleki is Thabane's bitter rival from their days in the LCD. Indeed, Thabane had spoken openly at his party's electoral campaigns about the alleged corrupt

1 Lesotho's currency Maloti is pegged to the South African Rand on 1:1 basis 
tendencies of Moleleki. Moleleki had equally lambasted Thabane during his own party's rallies. Moleleki's appearance before a court of law in June 2013 was his second in four months. In March 2013 he had appeared before the High Court together with four directors of the company Refela Holdings. In the earlier case, according to Molomo and Tlali (2013, p. 6), Moleleki had faced three charges for allegedly

helping the four men and their company to acquire a prospecting mining lease without having applied for it. The second charge was that he abused his ministerial position and violated the provisions of Mines and Minerals Act 2005 "for the purposes of obtaining an undue advantage for himself and / or for the" four men and their company.

The two cases against Moleleki were yet to be heard at the time of writing. They were postponed on numerous occasions due to his gravely ill health, from which he has since recovered.

Timothy Thahane, an LCD MP for Likhetlane Constituency, became one of the high-profile politicians to be charged with corruption under Thabane's administration. Thahane, who was also the Minister for Natural Resources, was fired from his ministerial position after his brief appearance before the Maseru Magistrate's Court in November 2013. He had appeared in court on two accounts of fraud and bribery totaling more than M43 million (Ntaote 2013, p. 8). His firing was announced by the then Acting Prime Minister and LCD leader, Mothejoa Metsing.

During his official announcement about the firing, Metsing said that Thahane faced serious charges, and that it was necessary to relieve him of his duties to preserve the integrity of the Cabinet. Interestingly, Metsing was also not spared the wrath of the Thabane administration's 'anti-corruption crusade'. Metsing later made several appearances in Lesotho's courts in connection with alleged fraud and corruption.

In August 2014, Metsing and the Minister for Communications, Science and Technology, Selibe Mochoboroane, together with three other people, appeared before the Maseru Magistrate's Court. They were all accused of allegedly contravening the provisions of the Penal Code Act 6 of 2010. Their charge sheet read as follows:

during or about $15^{\text {th }}$ March ... the accused did unlawfully and with intent to defraud, misrepresent to the Government of Lesotho and / or Minister of Finance that the M53,095,027.00 they requested from the Ministry of Finance and was allocated, was for the procurement of 
yellow plant and its insurance on behalf of the Maseru City Council ...

(Tefo 2014b, p. 2)

The same newspaper report goes on to state that soon after the charges were read aloud before the court, Crown Counsel Advocate Kananelo Khoboko surprised the packed courtroom when she announced that the case was being withdrawn. The reason given was that this would enable the prosecution to reconsider its position in the case, and allow the investigations to be completed.

The withdrawal of the charges was not all that surprising given the tension within the coalition government, which had begun to split the public service apart. The Office of the Director of the Public Prosecutions (DPP) had also been affected, as it was clear that the DPP Leaba Thetsane was in the LCD camp. Thetsane had completely lost the trust of Prime Minister Thabane and his followers, who accused Thetsane of not taking high profile cases in his office to the courts. Thabane had tried to push both Thetsane and the Attorney General out of office on the grounds that they had passed the retirement age of 55 for public servants. Thetsane challenged his dismissal, and the Court of Appeal ruled in his favour.

It seems reasonable, therefore, to infer that the withdrawal of charges amounted to political sabotage aimed at aiding LCD politicians. This inference is supported by the fact that in a similar twist of events in November 2014, DPP Leaba Thetsane withdrew charges against the fired Minister for Communications, Science and Technology, Selibe Mochoboroane. Thetsane complained that the charges had been preferred behind his back as the head of prosecution (Tefo 2014b, p. 2). After the withdrawal of the case, Metsing pledged support to Thetsane. Metsing 'told the supporters that if Advocate Thetsane could be threatened by any political leader for withdrawing the charges he and his allies would protect the DPP, fight for him and die along with him if need arises' (Tefo 2014b, p. 2)

In yet another interesting legal twist, Metsing filed a case before the Constitutional Court in August 2014. He asked the court to declare as illegal the seizure by the DCEO of his banking particulars from three local banks. The banks were listed together with the DCEO as respondents in the application. However, on 25 February 2015, three days before the snap elections, a panel of South African judges dismissed the application and said that the anti-corruption agency had acted within the parameters of the law (Tefo 2015, p. 2).

Two of the country's top judges, Nthomeng Majara and T'seliso Monaphathi, had earlier recused themselves from the case after Metsing's application to have only foreign judges presiding over his case. The DCEO had wanted Metsing to shed some light on alleged dodgy tenders and strange deposits into his bank accounts between April 2013 and January 2014. The total deposits made at the three banks amounted to M328 000, M118 000, and M524 965 respectively (Tefo 
2015, p. 2). In turn, Metsing accused the DCEO of having violated his privacy and family life by seizing his banking particulars without his consent in its investigation to probe the corruption charges against him (Motopi 2014, p. 6).

As mentioned earlier, these are just a few examples of corruption cases that were brought before the courts against government officials, under Thabane's administration. The fallout between the coalition partners was not limited to the executive branch; it also became evident in the National Assembly. This is discussed in the next section.

\section{Trouble Extends to Parliament}

An incident that marked the start of a dramatic turn of events in the Lesotho Parliament was when two ABC MPs, Thabiso Lit'siba and Mophato Monyake, crossed the floor. Their departure left the coalition with 59 seats. Lit'siba joined the main opposition party (DC), and Monyake became an independent MP and launched his own party, the Progressive Democrats (PD) in November 2014. Both men claimed to be disillusioned with the $A B C$ over a number of issues, among them Thabane's alleged autocratic leadership. Interestingly, Monyake only complained about Thabane allegedly autocratic leadership after Thabane had fired him as Minister for Law and Correctional services. Lit'siba, by contrast, had reportedly been unhappy with his leader for overlooking him for ministerial posts. A former university lecturer who had resigned from academic life a few months before the 2012 elections, Lit'siba had probably had high expectations. He was understandably unhappy to be overlooked for individuals who had far lower academic qualifications.

Lit'siba and Monyake had won constituencies and were therefore eligible to cross the floor in Parliament; the country's Constitution allows only constituency MPs to do so. When it became clear that the ABC could no longer hold on to the two MPs, the opposition parties forged an alliance to move a no-confidence vote in the government. Lit'siba and Monyake attached their signatures to the agreement forming this alliance. All but one party within the Bloc signed the agreement, apparently in protest over the unfulfilled promises of rewards for supporting the government. The no-confidence motion was filed by Geremane Ramathebane, leader of Basotho Batho Democratic Party (BBDP). The BBDP was a small party that had gained a single compensatory seat after the 2012 elections.

In an effort to save their government, three MPs from the ruling alliance challenged the legality of the motion in the High Court and asked the court to stop the motion. The application gave the coalition government a life-line, as the Speaker denied the tabling of the motion pending the outcome of the case. In the face of this uncertainty, the government moved for Parliament to be 
closed sine die. During the period in which Parliament remained closed, the mover of the no-confidence motion, Ramathebane, was arrested and locked up for 48 hours before he appeared in court. On appearing before the Maseru Magistrate's Court, Ramathebane was charged for allegedly registering his party fraudulently in 2006. The court granted him bail, and at the time of writing the case was yet to be finalised.

Parliament was finally opened again. In the midst of the deepening rift between the two largest parties in the coalition, in June 2014 the LCD leader (Metsing) announced his plans to remove his party from the ruling coalition and form a new government, together with former Prime Minister Mosisili's DC. In announcing the planned withdrawal at a press conference in Maseru, Metsing said they had decided they could 'no longer endure the humiliation that the Honourable Dr Thabane is inflicting upon the LCD by his unilateral and undemocratic conduct' (Zihlangu \& Ntaote 2014, p. 1).

Sensing the imminent ouster from government, Thabane advised King Letsie III to prorogue Parliament for nine months. Thabane's move was in line with Section 83(1) and (4) of the Constitution. Section 83(1) reads: 'The King may at any time prorogue or dissolve Parliament.' Section 83(4) states that 'In the exercise of his powers to dissolve or prorogue Parliament, the King shall act in accordance with the advice of the Prime Minister.' Parliament was accordingly prorogued in June 2014. It was at this juncture that the opposition parties, in concert with the LCD, sought intervention from the SADC.

As noted earlier, the SADC Troika appointed South African Deputy President Cyril Ramaphosa to facilitate the return of Lesotho to political normalcy and to help stabilise the country's deteriorating security situation. Ramaphosa held various meetings that led to the reopening of Parliament in September 2014, to prepare for holding new elections in February 2015. While all these developments unfolded, there was not a single effort to officially gauge the opinion of the general public. Everything was to be decided by members of Parliament alone, in line with Lesotho's system of representative democracy. As in other electoral democracies, Lesotho's system sets an electoral minimum for the electorate. Whatever the MPs decide is assumed to be the view of the constituencies they represent.

One of the conditions upon which Parliament was reconvened in September 2014 was that its business be restricted to the passing of an elections budget and amendments necessary for the elections. The first of these conditions was upheld but the second was not. In opening the parliamentary session, King Letsie III strongly advised the MPs to place their personal interests after the nation's interests. The King was visibly infuriated, and contrary to the norm he delivered an unwritten speech. He repeatedly reminded the MPs that they had the power to 
amend clauses of the Constitution which they no longer wanted. This was clearly a response to accusations levelled against him by the opposition, namely that he had used the country's Constitution to approve the 'advices' made to him by the incumbent Prime Minister Thabane.

Parliament was finally dissolved in October 2014 and the elections were set for 28 February 2015. However, the failure to effect constitutional and electoral amendments in preparation for the new elections, and the failure to adequately address security concerns, implied a lost opportunity for Lesotho. These circumstances have kept the country on a knife's edge. Later sections of this paper deal with this argument further.

A number of points can be observed from the conflict discussed above, which rocked both the executive and Parliament. First, it is clear that the anti-corruption crusade by Thabane's administration was the main source of conflict. There are two schools of thought about this crusade. On the one hand, the LCD saw it as a witch-hunt that targeted only LCD ministers. On the other hand, Thabane and his $\mathrm{ABC}$ disputed the LCD's claim, saying that the crusade targeted anybody who engaged in corruption, regardless of his or her background.

Although the genuineness of most of the charges is debatable, it seems likely that the charge against Ramathebane was politically motivated. The timing of the charge was suspect; it was laid immediately after he filed a no-confidence motion against the government. Most interesting about Ramathebane's charge was that the alleged crime had been reportedly committed in 2006, almost a decade before he was charged.

A second observation is the ease with which the DC and other small parties that were part of the Bloc were willing to join forces with the LCD to remove Thabane from power. This illustrates how Lesotho's politics are determined more by leaders' selfish interests and opportunism than by policy considerations. Just before the 2012 elections, Metsing and Mosisili had spoken ill of each other at their respective parties' campaigns. Metsing vowed never to work with Mosisili and said that doing so would undermine the wishes of his followers. This was after Mosisili had stated that his party would win the elections and would not need a coalition with any other party.

Similarly, the parties constituting the Bloc had initially supported the ABC-led coalition, because they agreed with the calls for Mosisili to be removed from power. That all these parties were now willing to come together, without any substantial policy changes being made, showed that their leaders were more interested in personal gain than in the kind of stability that is vital to service delivery.

The next section of this paper discusses in detail the February 2015 snap elections. 


\section{THE FEBRUARY 2015 SNAP ELECTIONS}

Despite being held at short notice, the 2015 general elections went smoothly and had no major problems. This smooth transition can be attributed to, among other things, the experience which the Independent Electoral Commission (IEC) staff have gained since the Commission's establishment in 1997. Since 1997 the IEC has run five general elections, two local government elections, and many by-elections. For the 2015 elections, the IEC kept most of the temporary staff it had engaged in 2012. This paid dividends because there was no need for extensive training.

One incident nearly compromised the smooth preparations for the elections. In October 2014, the IEC reported that 21 computers which had been used to register voters had been stolen from its storage rooms. Many political leaders reacted with shock to the news, fearing the theft would affect the authenticity of the registration process and the voters' roll. The IEC, however, assured the nation that the missing computers could not affect voter registration.

After intense police investigation, 17 of the stolen computers had been recovered by February 2015. Evidence showed that the computers had not been used to tamper with the voters' roll. The computers had been sold to unsuspecting students, who had used them for academic work. The supplier's report showed that the recovered computers had been formatted with normal software to make them operate like normal computers (Ntaote 2015a).

The disappearance of the computers led to the suspension of the long-serving Director of Elections, Mphasa Mokhochane, by IEC Chairman Justice Mahapela Lehohla. The suspension was 'for failing to timeously report the incident of the missing electoral machines to the Commission, raising suspicions of foul play' (Mokhethi 2015a). 'Mamatlere Matete was then appointed acting Director of Elections and was thrown into the deep end to run the 2015 elections. This scenario meant that the top brass of the IEC was mostly new. Lehohla had taken up chairmanship of the IEC only in December 2013, together with two new commissioners, Dr Makase Nyaphisi and Advocate 'Mamosebi Pholo. However, inexperience among the Commission's top officials did not impede the elections in any way.

Twenty-three political parties contested the elections. Despite the high number of registered parties, it was obvious from the start that the elections would be a 'two-horse race' between the ABC and the DC. Four other parties - the BNP, the LCD, the Popular Front for Democracy (PFD), and the newly-formed Reformed Congress for Lesotho (RCL) - were set to become 'kingmakers' for either the $\mathrm{ABC}$ or $\mathrm{DC}$, because it was clear that neither would win an absolute majority. The RCL was a splinter group of the LCD, led by the LCD's former secretary general, Keketso Rant'so. Rant'so had left the LCD together with some 
party stalwarts few months before the elections, accusing LCD leader Metsing of dictatorial tendencies. The rest of the parties merely added numbers, with their leaders trying their luck and hoping to get compensatory seats in Parliament through the proportional wing of the country's Mixed Member Proportional model. Table 2 below shows the final allocation of seats in the Lesotho's ninth Parliament after the 2015 elections.

Table 2

2015 Election results and Final Seat Allocation

\begin{tabular}{|l|c|c|c|c|}
\hline Party & Total votes & Constituency seats & PR seats & Total seats \\
\hline ABC & 215022 & 40 & 6 & 46 \\
\hline BCP & 2721 & - & 1 & 1 \\
\hline BNP & 31508 & 1 & 6 & 7 \\
\hline DC & 218573 & 37 & 10 & 47 \\
\hline LCD & 56467 & 2 & 10 & 12 \\
\hline LPC & 1951 & - & 1 & 1 \\
\hline MFP & 3413 & - & 1 & 1 \\
\hline NIP & 5404 & - & 1 & 1 \\
\hline PFD & 9829 & - & 2 & 2 \\
\hline RCL & 6731 & - & 2 & 2 \\
\hline Other 13 parties & 12353 & - & - & - \\
\hline Total & 563972 & 80 & 40 & 120 \\
\hline
\end{tabular}

Source: IEC Lesotho. National Assembly Election 2015 Results

\section{ANALYSIS AND INTERPRETATION OF RESULTS}

The aim of this paper is to show how the 2015 snap elections failed to address the structural problems that had led to the collapse of the first coalition in Lesotho. At this point it is worth giving a brief overview of how the main parties fared in the 2015 elections. After that, the main issue will be discussed.

\section{Performance of Main Parties}

This section focuses on the three parties that had formed the first coalition government: the ABC, the BNP, and the $\mathrm{LCD}$. The DC is also discussed because it had obtained the most seats in the 2012 elections, but had been relegated to the status of official opposition because it failed to earn support from other parties. The scope of this paper precludes a discussion of the factors responsible for the performance of the parties in the 2015 elections and is limited to the actual election results. 


\section{Democratic Congress}

Overall, the DC got more seats than any other party. As shown in Table 2 above, the DC won 47 seats, just one more than the ABC's 46 seats. Table 2 also shows that the DC won 37 constituency seats compared with 40 for the $\mathrm{ABC}$, but the $\mathrm{DC}$ had ten PR seats - four more than the ABC's six. The reason was that the DC won more national votes than the ABC.

In terms of the overall number of seats, the DC's performance reflects a very small decline relative to the 2012 elections. The party had won 48 seats in 2012, losing just one seat in 2015. In 2015 the DC obtained 218573 actual votes compared with 218366 in 2012, an increase of 207 votes. However, as a percentage of the national vote, the DC showed a huge decline. In 2012 the DC won $47.5 \%$ of the national vote, but in 2015 this dropped to $38.8 \%$. Another interesting point about the DC's performance is the pattern of its votes. The party's loss of urban constituencies continued in the 2015 election. The DC again failed to win even one of the eight Maseru city constituencies. In the other nine districts, it retained only three of the five mountain town constituencies that it had won in 2012.

\section{All Basotho Convention}

The $\mathrm{ABC}$ showed the greatest growth compared with other parties. It won 46 seats in the 2015 elections, 16 more than the 30 seats it had gained in 2012. In 2012 the $\mathrm{ABC}$ had won 26 constituencies, and in 2015 it managed to win 14 more - a total of 40 constituencies. The $\mathrm{ABC}$ also dramatically increased its national votes from 138917 in 2012 to 215022 in 2015. This meant the party increased its share of national votes from $30.2 \%$ in 2012 to $38.1 \%$ in 2015 .

The $\mathrm{ABC}$ has consistently maintained its dominance in recent years. This trend started in 2007 among urban constituencies, with the ABC winning all Maseru city constituencies and six other urban constituencies in six other districts. In addition to reclaiming the Hlotse town constituency which the LCD had won in 2012, in 2015 the ABC captured the Mokhotlong town constituency - which it had failed to win in all previous elections. Another highlight of the $A B C^{\prime}$ s performance in 2015 was that it captured all eleven constituencies in the Berea district.

\section{Lesotho Congress for Democracy}

Although the LCD ranks number three of the four parties under discussion and has twelve parliamentary seats, this party was the biggest loser in the 2015 elections (relative to 2012). The LCD captured twelve constituencies in 2012 but managed to win only two in 2015. Overall, the LCD had 26 seats in the eighth Parliament, dropping to 12 seats in the current (ninth) Parliament. Actual LCD national votes fell from 121076 in 2012 to 56467 in 2015, a fall of almost 50\%. The overall percentage share of LCD national votes fell dramatically from $26.3 \%$ in 2012 to $10 \%$ in 2015. 


\section{Basotho National Party}

Generally the BNP achieved slight growth in 2015 compared with 2012. The party managed to increase its share of parliamentary seats from five in 2012 to seven in 2015. Most importantly, in 2015 the BNP won one constituency; the party had last won a constituency seat in 1998. The BNP marginally improved its percentage share of the national vote. In 2012 it had $5.2 \%$ of all votes, and in 2015 it obtained $5.6 \%$. The actual number of votes rose from 23738 in 2012 to 31508 in 2015.

\section{Formation of the Second Coalition Government}

Despite their varying performances, the four parties discussed above remained central in the horse-trading that led to the formation of Lesotho's second coalition government. Unlike in 2012, the post-election negotiations of 2015 were not very intense. This was because it was evident even before the elections that the country was headed for another coalition government. As a result, parties had already decided on potential partners before polling day. For instance, it was clear from the start that the ABC, BNP and RCL would continue the relationship that they had enjoyed in the first coalition government. The RCL was officially launched just months before the elections. However, the party's leader, Keketso Rant'so, had begun to work closely with the ABC and BNP as soon as it became obvious that her relationship with Metsing (Rant'so's former leader in the LCD) was beyond repair.

By contrast, the DC/LCD alliance had already been formalised through an agreement which the two parties signed in June 2014. The agreement had been prompted by the LCD threatening to leave the coalition government. The DC had even at one stage suggested that the two parties should field only one candidate in the constituencies won by the ABC in 2012, to increase the alliance's chance of victory. The suggestion was rejected by the LCD on the grounds that the arrangement would minimise its PR seats. Sympathetic to the DC/LCD alliance were the five other small parties that had formed the Bloc in the eighth Parliament, as well as the Basotho (formerly Basutoland) Congress Party (BCP) - which had remained on cross benches in the eighth Parliament. All these parties had signed the no-confidence motion that was aimed at dethroning Thabane. For the five Bloc parties, supporting the DC/LCD coalition meant they could punish Thabane for failing to reward them for parliamentary support they had given his coalition.

These two pre-determined coalition partnerships were one way in which the 2015 elections failed to remedy Lesotho's political problems. Both partnerships were mainly marriages of convenience, based more on the desire to punish rivals than on principled ideals. Also, these partnerships left no room for the two biggest parties, the $\mathrm{ABC}$ and the $\mathrm{DC}$, to work together. This scenario prevented 
the grand coalition that some analysts believe was needed to improve Lesotho's political situation.

For instance, in his preliminary statement after the elections, Dr Raila Odinga warned that a 'grand coalition of the biggest parties would unite Basotho and "heal the wounds" thereby ensuring long-lasting peace in Lesotho' (Ntaote 2015b). Odinga was the head of the African Union Observer Mission during the Lesotho 2015 elections. Odinga's sentiments were later echoed by Professor Nqosa Mahao, who noted that 'with the ABC and DC in government, you would have consensus on institutional and constitutional reforms as they would be built around inclusivity and focus on national healing' (Ntaote 2015b).

Section 87 (2) of the Constitution of Lesotho states that the King shall appoint as prime minister the member of the National Assembly who appears to the Council of State to be the leader of the political party or coalition of political parties that will command the support of a majority of the members of the National Assembly'. The alliance of the ABC, BNP, and RCL had managed to pool together only 55 seats, whereas the DC/LCD had 59. Thus, neither of the two alliances was in a position to form a government on its own.

The absurdity of Lesotho's electoral model was once more exposed when smaller parties, some of which could not even win $0.5 \%$ of the national vote, were now able to decide the future of Lesotho's rule. For instance, the LPC had only managed to win only $0.4 \%$ of the national vote (IEC Lesotho: National Assembly Election 2015 Results). Of the two pre-determined coalitions, the DC/LCD alliance was better placed to woo these smaller parties. It came as no surprise when, a few days after the announcement of the election results, the DC/LCD alliance stated that it had gained the support of five smaller parties and would therefore be able to form a seven-party coalition government. Together, the seven parties had 65 seats.

The new government was to be led by Pakalitha Mosisili of the DC as the prime minister, and Mothejoa Metsing of the LCD was to become deputy prime minister. The five smaller parties that were included in the coalition government were the Popular Front for Democracy (PFD), Marematlou Freedom Party (MFP), Lesotho People's Congress (LPC), the BCP, and the National Independent Party (NIP). The PFD brought two seats into the new coalition, and the other four parties each contributed one seat.

The arrangement of the new seven-party coalition meant that Mosisili would return to the post he had lost in 2012 after having been in power for fourteen years. Metsing was able to retain the post he had occupied in the previous coalition government. The formation of the seven-party coalition government represents what Kadima (cited in Makoa 2008, p. 52) calls the 'office-driven approach'. In this approach, the main goal of political parties is to access power rather than necessarily being driven by fundamental similarities in their principles. 
Mosisili announced his Cabinet on Friday 27 March 2015. All seven parties were represented in the Cabinet. What is unique about the seven-party Cabinet is that neither Prime Minister Mosisili nor his deputy Metsing head any ministries. This situation was intended to ensure that 'the two leaders would not be "burdened" by ministerial posts that could "interfere" with the "supervisory" roles of ensuring an effective government' (Mohloboli 2015a, p. 2). The working relationship between the seven parties was formalised through a document titled 'The Coalition Agreement for Stability and Reform: Lesotho's Second Coalition Government Agreement', which was signed in April 2015. According to this agreement, the DC has sixteen ministers and five deputy ministers, and the LCD has five ministers and one deputy minister. Each of the four smaller partners that have one seat in Parliament has one minister, while the fifth (PFD) has both a minister and a deputy minister.

The composition of the new Cabinet showed that consideration of merit and capacity to perform were of secondary importance; more important was the desire to appease one's coalition partners in allocating the ministries. Also notable was Mosisili's failure to shrink the Cabinet, as he had promised to do on various occasions during the time he was excluded from the government. He had earlier been very vocal in criticising Thabane's 30 -member Cabinet, saying it was a waste of resources to have such a large Cabinet in a small country like Lesotho. However, instead of reducing the Cabinet as promised, Mosisili increased it to 35 members. Also noteworthy in the new Cabinet was the placing of the Ministry of Defence away from the prime minister's portfolio. This literally implies the prime minister is no longer the commander-in-chief, as was always previously the case. All these developments are likely to pose challenges for future governance in the country.

\section{Elections Test Passed, but Dilemmas Lie Ahead}

The analysis in this article is made within the context of electoral democracies. According to Schedler (2002, p. 37, cited in Masunungure 2014, p. 97), electoral democracies do hold free and fair elections. However, they do not ensure other vital dimensions of democratic constitutionalism such as the rule of law, political accountability, bureaucratic integrity, and public deliberation. This paper argues that although Lesotho has managed to hold undisputed elections that legitimise the resultant government, such elections have not ensured the other aspects that are central to functional democracies. For instance, Lesotho has a precariously volatile security situation and a somewhat loose Constitution that is vulnerable to abuse by politicians.

When Parliament reconvened in September 2014, the feeling among some sectors of the Basotho Nation was that laws regulating floor-crossing in Parliament 
needed to be reviewed. Similarly, the Constitution was said to require amendment to provide for coalition governments. As Raila Odinga of the African Union Observer mission rightly observed, 'the Lesotho Constitution does not provide for a robust mechanism for the operationalisation of a coalition government, nor does it effectively anticipate the dynamics of coalition politics' (Kabi 2015, p. 7). There was also a need to clarify the prorogation clause, as there were some suggestions that it was amenable to abuse.

These legislative reviews were not done, as noted earlier in this paper. The omission has left the country with challenges similar to those that led to the collapse of the first coalition government. The possible future scenarios for Lesotho politics are discussed below in relation to each of these points.

\section{Floor crossing}

Of the 120 members of Lesotho's National Assembly, only 80 - who had won constituency seats - are legally allowed to cross the floor in Parliament. Floorcrossing has over the years been accompanied by controversy. It has always been a central feature in the collapse of governments, dissolution of Parliaments, and subsequent holding of snap elections in Lesotho.

In 1997, controversy erupted over the LCD's usurpation of rule. The controversy arose from the fact that the party was declared government by the Speaker after $41 \mathrm{MPs}$, including then Prime Minister Ntsu Mokhehle, crossed the floor from the then ruling Basutoland Congress Party (BCP). The party had been formed and registered few days earlier. Similarly, the 2007 snap election followed the floor-crossing by 17 LCD MPs and one independent legislator, all of whom crossed over to the ABC. There was again a serious controversy in 2012 when the DC relegated the LCD to the opposition benches after $45 \mathrm{MPs}$ left the LCD to join the DC that was registered days earlier. The instability that led to the dissolution of Parliament in 2014 was a direct result of the floor-crossing by two ABC MPs.

Based on this history, some sections of Basotho feel that for the sake of stability and to grow the country's shaky democracy, floor-crossing needs to be regulated. In discussing the challenge of floor-crossing, Matlosa and Shale (2008, p. 148) pointed out that 'floor crossing in Lesotho, as elsewhere, takes place without the consent of the rank and file membership, hence some observers perceive it as unfair and a betrayal of the voters.' For this reason, floor-crossing undermines the accountability of MPs to the electorate.

Failure to amend the law on floor-crossing means that the most crucial element that has destabilised Lesotho's Parliament in the past remains unresolved. The consequences are likely to continue to be bitter for the Basotho Nation. Firstly, the government may collapse if MPs defect from the ruling alliance at any point. Secondly, the constituency MPs can hold their respective alliances - in both the 
opposition and ruling parties - to ransom simply by threatening to defect to rival alliances. The status quo also means that the prime minister has very little, if any, control over his ministers who gained parliamentary seats by winning constituencies, because they could threaten him with defection if he reprimands them. The repeat of Monyake's case remains a possibility. As already noted, Monyake crossed the floor and left the $\mathrm{ABC}$ after he was fired as a minister by Thabane. Limited control over ministers by the prime minister can only lead to poor service delivery for the ordinary Mosotho on the street.

\section{National Constitution versus coalition agreements}

There were suggestions, during the tension under the ABC-led coalition, that the Lesotho Constitution was not suitable for coalition governments. This became evident whenever opposition members called during phone-in programmes held by some local radio stations, to argue that in a coalition there are as many prime ministers as there are coalescing parties. However, the eighth Parliament never took the time to address this concern. To date, the Constitution still grants the prime minister executive powers to advise the King to make several crucial decisions.

It is important to note that the Constitution does not necessarily require the prime minister to consult with his party, in the case of a one-party government, or with his partners in the case of a coalition government. Because Thabane applied this power, Metsing accused Thabane of taking arbitrary decisions without consulting him. In one of his public statements after the announcement of the seven-party coalition, returning Prime Minister Mosisili promised to 'avoid Thabane's "blunders" by ensuring that all the seven parties in his coalition government obey the principles that govern coalition governments' (Mohloboli 2015b).

In relation to the country's Constitution, which is the supreme law, Mosisili stated that 'in as much as we would be expected to obey the Constitution and rule of law in this country, as partners, we should abide by our coalition agreements and not consider them as mere pieces of paper' (Mohloboli 2015b). The coalition agreement which regulates relations within the coalescing parties emphasises the elements of trust and respect, but says little about the constitutional powers of the prime minister. This omission is likely to pose serious problems should the relations sour, which is almost certain to happen considering the dynamics of Lesotho's politics. For instance, clause D10 of the agreement says that parties may agree to disagree. By contrast, clause E6 says that any minister can be dismissed if he or she loses the confidence of his or her party. The same clause states that if a minister loses the prime minister's confidence, the minister will be dismissed after consultation with his or her party. This clause directly contrasts the Constitution, which gives the prime minister full powers to appoint and fire ministers. 
It remains to be seen how Mosisili will effectively balance his constitutional powers as prime minister against the coalition agreement, particularly where the two are in conflict or when he cannot get consensus from his partners. It will also be interesting to see how Mosisili will act if he wants to fire any of the five ministers from the five smaller parties. All these ministers are leaders of their parties, and according to the coalition agreement Mosisili can fire a minister only after consulting that person's party. This implies that he would have to consult these ministers over their own dismissals.

The author contends that balancing the need for stability among the sevenparty coalition against the constitutional provisions will be an uphill battle, and that this balance can be achieved only at the expense of the ordinary Basotho. Stability within the coalition can ideally be maintained through consensus. The reality, however, is that such consensus is extremely difficult if not impossible to achieve. It is for this reason that the Constitution does not require evidence of consultation before prime ministers make their final decisions.

Mosisili's attempts to balance the stability of his seven-party coalition and his constitutional prerogatives as prime minister will be further complicated by his deputy, Metsing, who previously accused Thabane of being non-consultative and authoritarian. Indeed, Metsing made the same accusation against Mosisili during the latter's days as the leader of the LCD. Metsing complained that Mosisili did not consult him as the party's secretary general. Based on his history, one might expect that Metsing will continue to demand that Mosisili should consult him when taking decisions. Metsing's claims of non-consultation by Thabane, were made perhaps because he was frustrated to once again be the bridesmaid and not the bride, which seems to be the story of his political career (Allison 2014, p. 8). Coincidentally, Metsing finds himself to be a 'bridesmaid' yet again in the new coalition government.

\section{Prorogation law}

Following the outcry by the LCD and other opposition parties when Parliament was prorogued in June 2014, there was a need for Parliament to review the prorogation section (83) of the Constitution of Lesotho. This review should have happened when Parliament reconvened in September 2014. The parties had complained that Thabane had abused the law to ensure he stayed in office. Such a review might have resulted in repealing the law or at least specifying conditions under which it can be applied. However, the embattled Parliament never took the opportunity to do this review.

Although the topic was never officially aired in Parliament, Thabane did not support the call to review the prorogation law. Dismissing the opposition parties' call to scrap the law, Thabane insisted the call was unfounded and was being made 
only by leaders of small parties, who knew they had no chance of becoming prime minister. Probably because they shared a similar view with Thabane, the DC and LCD did not call for the outright repeal of the law in question but complained about it being amenable to abuse.

To date, prorogation of Parliament remains constitutional in Lesotho. It seems fair to expect that Mosisili - despite his protests when Thabane applied the same law - will apply it whenever his rule is under threat. Indeed, Mosisili has previously used both the prorogation and the dissolution clauses to save his rule. He prorogued Parliament in 2001 and 2009. In both cases, the prorogation of Parliament allowed for processes that would ensure the continuation of Mosisili's rule. As mentioned earlier in this paper, he also dissolved Parliament prematurely in 2006 to avert a no-confidence vote.

\section{An Opportunity Missed}

The above paragraphs have described how the 2015 elections have brought temporary relief rather than a cure for Lesotho's political 'sickness'. A true remedy, or at least a reduction in the country's problems, would require comprehensive reforms in both the constitutional and institutional realms. This does not imply being overly pessimistic or ignoring the capability of Lesotho's politicians to maneuver around situations, including the Constitution, to achieve their objectives. They have done so before and are likely to continue to do so if circumstances permit such maneuvering. It is therefore important that all possible steps be taken to tighten up the country's Constitution to minimise its abuse.

The period just before the elections would have been the best time to develop lasting solutions for Lesotho's political problems. Undertaking most of the necessary reforms needs a two-thirds majority. Obtaining this majority would have been relatively easy in the pre-election period, because no party stood to lose directly from reforms - at least not immediately. Now that the elections are over and a new government is in place, it is unthinkable that the ruling coalition and the opposition will give each other the required parliamentary support to pass bills aimed at reform. The previous Parliament also failed to introduce reforms.

An alternative that would have provided the required majority would have been the coalition of the two largest parties. However, that was also not to be. Lesotho's predicament is summarised by Professor Nqosa Mahao (Ntaote 2015b) as follows:

the other reason why a grand coalition would have been ideal for Lesotho was constitutional and institutional reforms ... Now the interesting thing is some of those issues that need to be 
constitutionalised require a much bigger consensus by the public and parliament. For instance, there are issues such as parliament's prorogation which, according to the constitution, cannot be amended unless you refer them to a referendum. The constitution says you may only avoid a referendum if you win two-thirds majority for the amendment in parliament. Now the likelihood that any of this patched mandate comprising many parties would attain a two-thirds majority seems to be a little bit of wishful thinking.

\section{Precarious Security and Compromised Rule of Law}

Political stability in Lesotho might have been restored at least in the short run, and the new coalition government has the legitimacy which was lacking in its predecessor - to the point of virtually obliterating the previous regime. However, the security crisis and challenges to the rule of law are likely to persist. Tension between the army and the police was briefly reduced by sending the three security chiefs on leave of absence under the Maseru Security Accord. But serious issues relating to national security and the rule of law remain unresolved.

For instance, the perpetrators of bombings at the homes of Police Commissioner Khothatso Tsooana and Thabane's partner Liabiloe Ramoholi in January 2014 have not yet been charged. The police have complained that the army refuses to hand over eight officials for questioning in connection with the bombings. Disagreements about the release of these officials illustrate the souring in the relationship between the two security institutions. The conflict culminated in attacks on three Maseru police stations by the army in the late hours of 30 August 2014. During the raid, army members reportedly ransacked the police headquarters and demanded dockets and files pertaining to high-profile cases which the police were investigating (Ntsukunyane 2014, p. 4). One police officer was killed and nine were severely injured in the attacks.

During the same night, the army raided Thabane's official residence in what many observers have labelled as a coup attempt, only to find Thabane had fled to South Africa. No-one has appeared before a court of law in connection with any of these crimes. Only when the perpetrators of such attacks are brought to book can there be any hope for restoring normal security and the rule of law in Lesotho.

The rule of law was also compromised during the tenure of the ABC-led coalition. Certain ministers and high-ranking officials of the LCD defied legal decisions taken by the then Prime Minister Thabane, and at times vowed publicly to disobey national laws that did not suit their party's interests. One example was when former Minister of Communications, Sedibe Mochoboroane, forcefully remained in office despite being fired by Thabane. These officials could get away 
with what were clearly illegal acts because of the support they had from the army. For as long as army members 'remain above the law', rule of law will not be restored any time soon in Lesotho.

One of the two main terms of reference for the facilitation which Ramaphosa was asked to provide was to prioritise resolving the security issues that had precipitated Lesotho's political instability. He failed to do so, focusing instead only on a quick-fix solution: the elections. The security crisis remains a time-bomb that will certainly explode in the face of Basotho.

At the the time of writing, the issue of the command of the Lesotho Defence Force remains unresolved. The new coalition government has not yet publicly stated its official stance about the future of Lieutenant Generals Tlali Kamoli and Maapara-nkoe Mahao in the army. Commenting on Lesotho's security crisis, former member of the Military Council during the military regime, Colonel Sekhobe Letsie (Mokhethi 2015b, p. 4), said:

the facilitator should have worked on security even before suggesting the lifting of the prorogation of parliament. Now the February 28 general election has not brought any solution but total destabilization of the country. The confusion within the army should have first been settled so that it was clear who the commander was before going for the polls.

Recent developments in Lesotho suggest that the army's influence in the country's political affairs is set to continue under the new government, with the possible return of General Tlali Kamoli. This possibility became evident soon after the agreement forming the seven-party coalition was announced. Mosisili and Metsing corroborated each other in media statements, saying that Kamoli would be recalled as the commander of the Lesotho Defence Force. Metsing had enjoyed the support of the army during the troubled era of the first coalition government, and Mosisili is a well-known admirer of Kamoli. It was Mosisili who had appointed Kamoli to head the army just weeks before the 2012 elections. During Kamoli's leadership, the army had refused to hand over to the police those army officials who were wanted for questioning in relation to the criminal acts described earlier.

Kamoli himself reportedly had a case of high treason investigated against him after the events of 30 August 2014 (News 2414 September 2014). With certain high-ranking government and army officials having existing and potential cases to answer before the courts of law, it is likely that these cases will be swept under the carpet by the new coalition government. The Basotho Nation might never learn who the perpetrators of some of those crimes were. Had Ramaphosa's facilitation 
treated the security crisis as a priority and given it thorough attention, the current uncertainty over the rule of law could have been averted.

This failure to normalise the security situation in Lesotho, and the possibility that high-profile criminal cases will be swept under the carpet, is observed as follows:

Not once, during the six months of SADC "facilitation" efforts, up through today, have SADC officials - particularly its lead mediator in Lesotho, South African Deputy President Cyril Ramaphosa touched on the mutinous army revolt on 30 August last year. ... The enduring mystery of what exactly happened that day - who did what and why - would, if exposed, likely destabilize Lesotho once more. It would also rattle surrounding South Africa, which relies heavily on Lesotho's water. And it'd unravel the desperate, quick-fix efforts by the Southern African Development Community (SADC) - the region's diplomatic bloc, led by South Africa itself - to restore "peace and security" to Lesotho. In other words, it's in no-one's interest to unlock the truth.

(Jordan 2015)

The centrality of the army to the political survival of certain politicians in the Lesotho government is already plain to see. Metsing is on record as having said that his party regretted not having demanded control over the security and judicial ministries when it joined the coalition government in 2012. Interestingly, the defence ministry is now under the control of the LCD, and Metsing's right-hand man, T'seliso Mokhosi, is the new Minister of Defence. This arrangement deviates from the old tradition of having the prime minister also act as the Minister for Defence. It is a novel arrangement to have a head of government who does not have direct access to the security forces. This scenario itself implies limited powers for Mosisili, should he devise policies that are unfavourable to Metsing and his party or to individuals in the army's top brass. It suggests a vulnerability to a potential security crisis, which could be similar to the one Thabane went through when he lost the control and respect of the army.

\section{CONCLUSION}

The hurried ('snap') February 2015 elections succeeded in forming a new government of Lesotho. The elections gave this government the legitimacy that its predecessor had completely lost. But as Schendler has noted in his description of electoral democracies, simply holding an election does not ensure the existence of all the elements necessary for a functioning democracy. Lesotho appears to be 
a case in point. The new coalition government still faces the emergence of the same problems that paralysed the first coalition government. Failure by political parties to implement the legal and institutional reforms that would reconcile the coalition agreements with the national Constitution has left the new prime minister in an awkward position, and threatens the sustainability of his new government.

In addition, Ramaphosa's focus on the seemingly quick solution of holding an election, rather than on solving the security crisis in the country, has created serious uncertainty about upholding the rule of law. The relations between the police and defence forces remain sour. The alliance between political leaders who face criminal charges and the military - whose top command also faces possible legal charges - will surely block any efforts to bring these high-profile suspects before the courts of law. All these factors suggest that the 2015 elections have failed to provide a long-term solution to Lesotho's political and security problems. Ironically, the search for such a solution was the main reason that the snap elections were held in the first place.

\section{REFERENCES}

\section{Books, articles and other publications}

Allison, S 2014, 'Lesotho: Personality, not politics', The Post, 4 December, p. 8 Heywood, A 2007, Politics ( $3^{\text {rd }}$ ed), Palgrave Macmillan, London.

Jordan, M 2015, 'Op-ed: Lesotho's continuing criminal cover-up', Daily Maverick, 24 March, viewed 26 March 2015, http://www.dailymaverick.co.za/ article/2015-03-24

Kabi, P 2015, 'AU recommends constitutional reform', Public Eye, 24 March, p. 7. Kadima, D 2006, 'The study of party coalitions in Africa', in Kadima D (ed), The Politics of Party Coalitions in Africa, EISA, South Africa.

Makoa, FK 2008, 'Party alliances and political coalitions during the 2007 general elections in Lesotho', Journal of African Elections, vol. 7, no 1, pp. 50-65

Masunungure, EV 2014, "The "menu of manipulation" and the 2013 Zimbabwe elections: towards explaining the "technical knockout"', Journal of African Elections, vol. 13, no 2, pp. 94-121.

Matlosa, K \& Shale V 2008, 'The impact of floor crossing on electoral politics and representative democracy in Lesotho', Journal of African Elections, vol.7, no 1, pp. 138-152.

Mohloboli, K 2015b, 'Mosisili vows to avoid Thabane's "blunders"', Lesotho Times, 12 March, viewed 27 March 2015, http: / / lestimes.com/mosisili-vows-toavoid-thabanes-blunders / \#sthash.c8SlcAzt.dpuf.

Mohloboli, K 2015a, 'Mosisili in cabinet dilemma', Lesotho Times, 19 March, p. 2. Mokhethi, S 2015a, 'Mokhochane dares IEC', Public Eye, 20 March, viewed 28 March 2015, http:/ / publiceyenews.com/site/2015/03/20/mok. 
Mokhethi, S 2015b, 'Army allowed itself to be used by politicians: former LDF officer speaks on August 30 events', Public Eye, 10 April, p. 4.

Molomo, N \& Tlali, T 2013, 'Moleleki faces two charges of fraud', Sunday Express, 22 June, p. 6.

Motopi, L 2014, 'Metsing corruption trial continues', Public Eye, 9 September, p. 6. Ntaote, B 2013, 'Thahane's dismissal hailed', Lesotho Times, 7 November, p. 8.

Ntaote, B 2015a, 'IEC allays fears over stolen computers', Lesotho Times, 11 February, viewed 16 March 2015, http: / / lestimes.com/iec-allays-fears-over-stolencomputers / \#sthash.sRAYu0Xk.dpuf

Ntaote, B 2015b, 'Mahao calls for grand coalition', Lesotho Times, 5 March, viewed 29 March 2015, http:/ / lestimes.com/mahao-calls-for-grand-coalition/\#sthash. AfsWGqir.dpuf

Ntsukunyane, L 2012, 'Shake-up in Lesotho Defence Force', Lesotho Times, 12 March, viewed 16 March 2015, http:/ / www.lestimes.com/shake-up-inlesotho-defence-force

Ntsukunyane, L 2014, 'Cops come out of hiding', Lesotho Times, 4 September, p. 4. Tefo, T 2014a, 'Metsing angry over corruption charges', Sunday Express, 4 August, p. 3.

Tefo, T. 2014b, 'We are ready to die for DPP: Metsing', Lesotho Times, 20 November, p. 2.

Tefo, T 2015, 'Metsing on the ropes', Lesotho Times, 26 February, p. 2.

'Too risky to arrest Lesotho's coup leader - report', 2014, News 24, 14 September, viewed 16 March 2015, http: / / www.new24.com / Africa/ News/ Too-riskyto-arrest-Lesotho-coup-leader-report-20140914

Zihlangu, B \& Ntaote, B 2014, 'Coalition pact collapses', Lesotho Times, 13 June, p. 1.

\section{Documents}

Agreement to Form a Coalition Government of Political Parties: Subsequent to the May 262012 National Elections (Unpublished document)

Constitution of the Kingdom of Lesotho 1993, viewed 21 July 2015, http: / www. ilo.org / wcmsp5 / groups / public / ---ed_protect/ ---protrav / ---ilo_aids / documents / legaldocument/wcms_126743.pdf,

Independent Electoral Commission of Lesotho 2012, National Assembly Elections Final Seat Allocation May 2012, viewed 21 July 2015, http: / / www.iec.org. ls/index.php/ component/ content/ article?layout=edit\&id=73

Independent Electoral Commission of Lesotho 2015, National Assembly Election 2015 Results, viewed 21 July 2015, http:/ / www.iec.org.ls/index.php/ component $/$ content / article?layout=edit\&id=73

The Coalition Agreement for Stability and Reform: Lesotho's Second Coalition Government Agreement April 2015, viewed 21 July 2015, http://www. gov.ls / documents / The $\% 20$ Coalition $\% 20$ Agreement $\% 20$ for $\% 20$ stability $\% 20$ and $\% 20$ reform.....Final $\% 20$ agreement $\% 2031 \% 20 \mathrm{March} \% 20$.pdf 